\title{
Perceived pervasive skills acquired through educational games in an accounting undergraduate degree

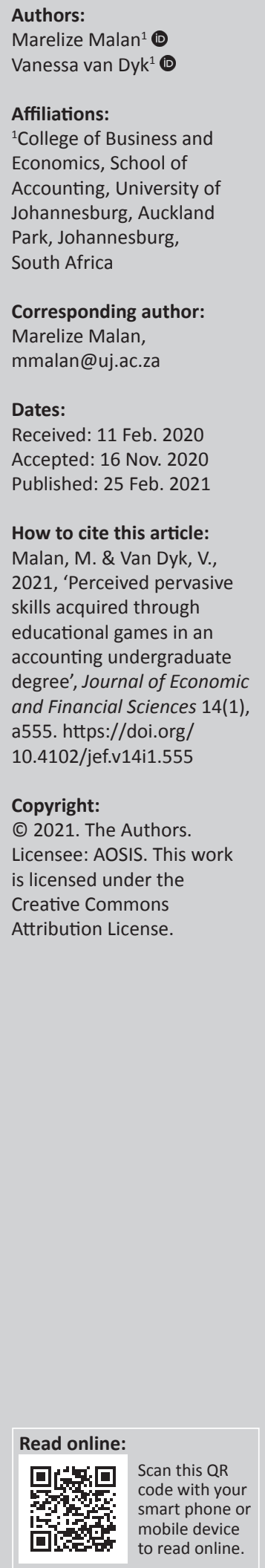

\section{Orientation: Learning should be active, experiential and fun.}

Research purpose: This study investigated the perceptions of students regarding the development of pervasive skills within an undergraduate accounting syllabus.

Motivation for the study: Game-based learning is an effective way to increase students' knowledge, evoke intense involvement in a collaborative setting and promote effective learning, which could result in the development of pervasive skills.

Research approach/design and method: The perceptions of second-year students were gathered through a questionnaire with closed- and open-ended questions. The questionnaire sought to compare the two games that are played by the same set of students, one in their first year of study in a commerce module and another in their second year of study in an accounting module.

Main findings: It was found that students enjoyed both games, particularly their collaborative nature and how they could learn from fellow students. The students perceived that the Monopoly board game primarily developed strategic thinking, critical thinking and professionalism whilst the 60 Seconds game developed teamwork, time management and communication (listening). The two games were, therefore, seen as effective learning aids since skills development occurred both within a formal, mark-bearing game and in an informal game with no bearing on the students' marks.

Practical/managerial implications: Learning through games can be interactive, practical and enjoyable and should be used as a tool to develop students' pervasive skills.

Contribution/value-add: This study also showed that it is not always necessary to spend much resource on a learning supplement. Both games proved to be effective learning tool in the development of pervasive skills.

Keywords: pervasive skills; student perceptions; game-based learning; accounting education; collaboration.

\section{Introduction}

Learning should be active, experiential and fun (Gee 2004). It is up to educators to create opportunities (Kolb \& Kolb 2005) in which this type of learning can occur and provide students with a valuable alternative to their 'normal' academic work (Viviers, Fouche \& Reitsma 2016:381). Game-based learning is an effective way to incorporate such learning into tertiary education so that the student is not just a passive recipient of knowledge but an active co-creator of it (Levant, Coulmont \& Sandu 2016).

Games are necessary and useful tools for learning. They provide enjoyment, adrenalinefuelled, creativity and social interaction (Boghian et al. 2019). Games require active participation, stimulate interest in a subject area, improve understanding and enhance the transfer knowledge (Chow, Woodford \& Maes 2011). Most games are played in teams and, therefore, all the benefits of cooperative learning are experienced by students who fully commit to the process (Boyle, Connolly \& Hainey 2011). Learning through play is highly sought after and game-based learning provides another resource for educators to develop technical and pervasive skills.

In accounting education, there has been significant pressure on educators to not only provide a curriculum with expert technical knowledge but also to include a range of pervasive skills that must be developed in students (Kavanagh \& Drennan 2008). The integration of such skills into the 
accounting curriculum is necessary but complicated, as educators need to find time and resources to incorporate these into the entire accounting education experience (De Villiers 2010; Stoner \& Milner 2010). Helliar (2013:518) stated that we need accounting educators who are 'learning consultants ... a new breed of teachers that are not introverted, too logical or scared of losing control'.

In South Africa, a university wishing to produce chartered accountant (CA) candidates must be accredited by the South African Institute of Chartered Accountants (SAICA) and must incorporate skills and competencies stipulated by the SAICA Competency Framework into its curriculum (SAICA 2019). Viviers et al. (2016) identified the following 12 pervasive skills based on their review of literature and the SAICA Competency Framework. These are communication (verbal), communication (listening), communication (writing), problem-solving, teamwork, time management, leadership, professionalism, ethical awareness, strategic thinking, critical thinking and influencing others. It is these 12 skills that form the focus of this study.

It is recognised that SAICA is currently revising the competency framework to adapt to the ever-changing role that accountants find themselves in. The revised competency framework, referred to as CA 2025, was also developed to (SAICA 2020):

[B]etter align competence of CAs with the escalating complexity in the business environment, globalisation, digital disruption and increased stakeholder demands, and to restore the public's trust in the CA profession. (p. 9)

However, the revised competency framework is currently still in draft and not yet ready for implementation by SAICAaccredited institutions.

\section{Research objective and structure}

In the undergraduate accounting programme at the SAICA-accredited university where this study was conducted, two games were played with students. Both games were non-digital and based on the popular entertainment board games of Monopoly and 30 Seconds. The Monopoly-based board game is played by students in their first year of study within a formal setting. Part of the students' subject mark is based on the results that they achieve in the game. The 30 Seconds-based game was played by the same set of students in their second year of study, very informally, within a tutorial class and has no impact on the subject mark.

The objective of this study is to determine the perceptions of students as to whether the two games that they played in their undergraduate degree assisted them in developing pervasive skills as required by the SAICA Competency Framework. The perspectives of students are of value as they can provide direct evidence of the games' effectiveness and, therefore, comment on the usefulness of the game in the development of pervasive skills (McEacharn 2005).
The contribution of this study is threefold. Firstly, it makes a comparison between two games played by the same set of students. These students are, therefore, in a unique position to provide insights into the pervasive skills that were developed and the learning that occurred whilst playing the games. Secondly, it determines the effectiveness of two nondigital board games. In recent years, digital games have received increased attention in the light of the Millennials and Gen Z (Carenys \& Moya 2016). Although digital games have gained traction during the last several years, there is still place for traditional, non-digital games to enhance students' learning and skill development. According to Boghian et al. (2019), there is a call to re-introduce board games into education as they can provide the same learning opportunities as digital games. Thirdly, as the study compares a very formal structured game that contributes to a student's subject mark, with an informal one that has no bearing on the mark earned by the student, it demonstrates that learning and skills development can occur even without formal assessment.

The rest of the article is structured as follows: the next section explores views on pervasive skills in the literature, with a particular focus on game-based learning in accounting education. Then, the nature of the undergraduate programme and the two games are discussed. This is followed by a description of the research methodology used to identify the skills developed through the two games. Lastly, the findings are presented and interpreted.

\section{Literature views Pervasive skills}

Pervasive skills, also known as soft, generic or employability skills, are those competencies and behaviours that are required by a graduate to be successful in the work environment (Barac \& Du Plessis 2014; Collet, Hine \& Du Plessis 2015; De Villiers 2010). For accounting professionals, that working environment will mostly be within a changing context where effective interaction with people, leadership skills and business acumen are necessary attributes (Barac \& Du Plessis 2014; De Villiers 2010).

Since 2000, when Albrecht and Sack called for a reform of accounting education, investigations have looked into what skills accounting graduates should possess apart from pure technical knowledge (Barac 2009; Jackling \& De Lange 2009). The gap between what employers expect from a graduate and the skills that they possess upon entry into the workplace (Bui \& Porter 2010; Webb \& Chaffer 2016) and whether the academic programme, the training programme or the workplace is responsible for the development of these skills (Barac \& Du Plessis 2014; De Villiers 2010; Strauss-Keevy 2014; Tymon 2013) has also been examined. Further research has also considered the suggested teaching methods to incorporate them in educational programmes (Andre \& Smith 2014; Brenner, Jeancola \& Watkins 2015; De Villiers 2010; Grimm \& Blazovich 2016; Levant et al. 2016; Viviers et al. 2016). 
Some of these suggested teaching methods incorporate case studies, group work, problem-based learning, as well as games and simulations into the accounting curriculum (Levant et al. 2016). All of these methods are based on the pedagogical foundation of active learning where the student is at the centre of learning and actively participates in creating knowledge and meaning (Levant et al. 2016). The educator is thus a facilitator who accompanies them along this learning journey (Carenys \& Moya 2016). An active learner is an engaged learner, displaying confidence in their learning and a strong involvement in the learning process (Lee, Shifflett \& Downen 2019). These learners will also follow the process of transforming their experiences so that knowledge is created and recreated (Kolb 1984; Kolb \& Kolb 2005). By playing educational games, learners are actively involved in the learning process (active learning), they have to act and experience the effects of their actions and choices (experiential learning) and create meaning and knowledge in their own way (constructivist learning) (Levant et al. 2016). The game environment also presents opportunities for learning pervasive skills (De Freitas \& Routledge 2013), as it is situated within the constructivist learning theory (Schunk 2012).

\section{Game-based learning}

Qian and Clark (2016) defined game-based learning ${ }^{1}$ as:

$[A] n$ environment where game content and game play enhance knowledge and skills acquisition and where game activities involve problem solving spaces and challenges that provide players/learners with a sense of achievement. (p. 51)

Different types of games exist, for example, serious games, entertainment games, digital games and business simulations.

A serious game, also referred to as an educational game, is a broad concept that encompasses all games, digital or otherwise, and has a specific learning objective or educational purpose (Carenys \& Moya 2016). Such games have been specifically designed to boost learning and are not merely an adaptation of an existing game (Boyle et al. 2014).

Entertainment games, on the other hand, have been adapted from their original content and principles to teach students specific concepts. Examples include traditional board games such as Monopoly, the well-known television quiz show 'Who Wants to be a Millionaire' and even the Wii dance game (Boyle et al. 2014; Tanner \& Lindquist 1998).

A digital game is any learning game played on a computer or online. It can include games either specifically designed for educational purposes or those adjusted from the entertainment genre (Carenys \& Moya 2016).

1.Game-based learning and gamification are sometimes used interchangeably. However, game-based learning relates specifically to the playing of games within an However, game-based learning relates specifically to the playing of games within an
educational environment, whereas gamification can also be used in non-educational settings (Silva et al. 2019).
A business simulation is one in which students in different groups run an online company within a specific business environment. They need to make real-time decisions as managers of the business and solve problems that managers will experience, all safely protected from the risk of real mistakes (Fito-Bertran, Hernandez-Lara \& Serradell-Lopez 2014).

The use of games has several benefits. It can improve the knowledge of a student in a specific subject area, whilst removing any anxiety regarding a specific aspect of the curriculum (Silva, Rodriques \& Leal 2019). It evokes intense involvement and engagement, mostly within a very social and collaborative setting (Carenys \& Moya 2016; Nitkin 2011). It is further beneficial in promoting effective learning as it is problem-based and immediate feedback is possible (McEacharn 2005; Qian \& Clark 2016). However, these benefits of game-based learning are not universally accepted and critics have called for more extensive research to determine whether meaningful learning indeed occurs (Qian \& Clark 2016). Huang and Hsu (2011) argued that games in education should be 'designed as a supplement, rather than as the core instructional method'.

\section{Game-based learning in accounting education}

Game-based learning has been successfully used in accounting education, with most of the recent efforts occurring in the digital gaming arena (Carenys \& Moya 2016). Huang and Hsu (2011) used free online games to teach their students personal finance concepts and found that the games achieved significantly higher learning outcomes - but only if used as a learning aid. Murphy (2005) created Word- and Excel-based Jeopardy! boards for teaching governmental accounting. The students who were surveyed found the learning process to be more interesting, felt more involved in the learning process and were forced to think more critically. Lee et al. (2019) also used Jeopardy! to teach accounting students Excel shortcuts and students reported an enjoyable learning experience. Silva et al. (2019) created the 'Accountingame' and the 'Marketingame', digital board games that require each player to answer a set of 200 questions, thereby increasing a student's knowledge of accounting and marketing subject areas. Seow and Wong (2016) created Accounting Challenge (ACE), a mobile app with a financial accounting and management accounting module, consisting of multiple choice questions. At the end of a game session, students can review their answers and learn from their mistakes.

Business simulations are another type of game often used in accounting and business courses. Towler, Lean and Moizer (2009) introduced their final-year students at a United Kingdom (UK) business school to the Business Strategy game. This game is based on a global business involved in the manufacture and sale of athletic footwear. The student teams compete against each other and are scored, based on predetermined metrics such as profit or market share at the end of the game. Similar to $\mathrm{Xu}$ and Yang (2010), 
they found that simulations encourage high-order thinking in students and require them to solve diverse problems quickly and collaboratively.

On the non-digital side, Tanner and Lindquist (1998) used the actual game of Monopoly in a group format and, after several turns, required teams to record their activities in the accounting records, to ultimately prepare an income statement and balance sheet. Similarly, Nitkin (2011) developed a board game, The Game of Business, for an introductory accounting class to reinforce the steps in the accounting cycle. Viviers et al. (2016) established a tax game, The Amazing Tax Race, in which student teams race against time to complete tax-related activities at several stations across campus. All these studies found tremendous value in the group structure of the games and reinforced the importance of cooperative learning.

The specific games played by students at the higher education institution where the study was conducted, as well as the undergraduate degree in which these modules are presented will be further explored.

\section{The undergraduate degree and description of the games \\ Bachelor of accounting programme}

In South Africa, the training of a CA commences with a 3-year undergraduate programme. At the SAICA-accredited university at which the study was conducted, this programme is called a Bachelor of Accounting (BAcc) or Baccalaureus Commercii (BCom) (Accounting). These programmes are designed in consultation with the SAICA to provide a wellrounded, technically focused education that equips graduates with the technical knowledge, proficiency and pervasive skills needed by the chartered accounting profession (SAICA 2019). The BAcc programme is recognised as the first requirement in the training of a student who desires to eventually practise as a CA. The programme is designed to prepare students for the Initial Test of Competence (ITC) with the SAICA ${ }^{2}$. In the undergraduate degree that is the focus of this study, two games are played: one in the first year of the programme and the other in the second year. In the first year, a board game is played as part of the Commerce 100 module. This is a formal game, developed in consultation with one of the major South African audit firms. In the second year, 60 Seconds (adapted from 30 Seconds) is played as part of the Accounting 200 subject. This is an informal game, played by students in one of their tutorial classes.

\section{Description of games}

\section{Board game (Commerce 100)}

This board game is played by students in the second semester of their first year as part of their Commerce 100 module. In

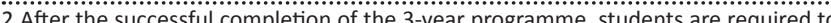
comp complete a Postgraduate Diploma or Honours Degree in Accounting. The ITC is the standard-setting exam, which is written after the completion of the accredited Postgraduate Diploma or Honours Degree in Accounting. It is an assessment of core technical and pervasive competence.
Commerce 100, students are exposed to the historical and modern approaches to management and the management tasks of planning, organising, leading and controlling. The board game was developed by one of the major South African audit firms, a stakeholder of the university. Designed in consultation with the lecturers, the game aims to expose students to practical decision-making and strategic thinking that will be required of them as managers of a business.

The board game is played in a way similar to Monopoly, with each student receiving a token and start-up money. Random groups of six students participate, facilitated by staff from the audit firm and lecturers from the university. Before the start of the game, each student is required to choose a company from one of six industries, for example, pharmaceutical or mining. The aim of the game is for a student to work up the corporate ladder of their company to eventually become the CEO and to accumulate money as they progress. As a student moves along the board with their token, the block that they land on will require them to either answer a technical question that relates to their Commerce 100 studies or to explain how they would respond to specific risks, opportunities or world events as they relate to their company. The facilitator and fellow students in the group will judge their answers; a successful answer results in a student receiving money and/or a promotion.

At the end of the game, the money that each student accumulated, as well as their position in their company is scored and that score is translated into a mark that counts towards their final Commerce 100 mark.

\section{0 seconds (Accounting 200)}

In Accounting 200, a year subject in the second year of the BAcc degree, students in the SAICA-accredited programme are introduced to International Financial Reporting Standards (IFRS) and are required to grasp the content of these IFRSs conceptually. The first tutorial class of the second semester is after a mid-year break of 5 weeks. The lecturers, therefore, decided to play a game of 60 Seconds (adapted from 30 Seconds) to refresh IFRS concepts in a fun way so that students could converse intelligently in accounting.

Playing cards were created by the lecturers and each card consisted of five key accounting concepts. In the tutorial class, the students are required to voluntarily pair up. One student in the pair is the describer of the cards and the other the identifier. The describer and the identifier rotate with each turn. Two pairs of students sit together to play the game against each other. In every round, one pair of a group has a chance to describe and identify the concepts on the cards, whilst the other pair judges their answers. The pair describing and identifying the five concepts is given 60 Seconds (adapted from 30 Seconds) to do so and is timed. According to the rules of the game, the describer of the concept is neither allowed to explain the word using the actual description of the concepts on the card nor translations of the concepts. The describer is also not 
permitted to use phrases such as 'sounds like' or 'rhymes with' or to give abbreviations of the word.

At the end of the tutorial class, the tutor determines if there were any unexplained or difficult concepts and these are clarified within the group. There are no scores kept and, therefore, there is no impact on the students' subject mark.

Based on the games and observation of the students' participation, a questionnaire was developed to investigate their perception of the pervasive skills developed in these games for research purposes.

\section{Research methodology Research method}

A mixed-methods methodology was considered appropriate (Tashakkori \& Creswell 2007) to gain insights into students' experiences and perceptions of the pervasive skills acquired through the playing of two games in their undergraduate degree. The mixed-methods design used for this inquiry meant that quantitative and qualitative data were integrated into the interpretation phase. This was done to determine the extent to which the findings from one data collection method complemented the findings of the other. The approach of combining quantitative data with comments and open-ended questions, enhanced the results, providing a richer perspective (Merino \& Aucock 2017; Viviers et al. 2016). Data were collected through a self-administered questionnaire using a purposive sampling technique (Palys in ed. Given 2008). Both closed- and open-ended questions were included in the questionnaire. Closed-end questions were asked to limit students' responses for more consistency and better comparability of responses. The open-ended questions were included in the questionnaire for deeper insight into the students' perceptions of the development of pervasive skills through their participation in the games.

\section{Data collection}

A link to the web-based questionnaire was emailed to the participants in the second semester. The students eligible to participate in the study had to be academically in their second year of study and must have been exposed to the two educational games in their undergraduate degree. The questionnaire consisted of two sections:

- Section 1 contained questions of a biographical nature that were used to create a profile of the participants.

- Section 2 contained the closed-and open-ended questions. The open-ended questions interrogated the students' perceptions on what skills they thought a CA should have and what they had learnt from playing the two games. The closed-ended questions determined whether they believed that the 12 pervasive skills (as listed in the introduction) had been developed when they played the two games. Each of the 12 skills was measured on a 5-point Likert scale, ranging from 1 (strongly disagree) to 5 (strongly agree).

An independent statistician analysed the quantitative data by means of Statistical Package for Social Sciences (SPSS). Data from the open-ended questions were analysed through a process of thematic content analysis (Henning, Van Rensburg \& Smit 2004). The thematic analysis followed several phases (Braun \& Clarke 2006) and started with gaining familiarity with the data, generating codes that would lead to themes, reviewing the themes and then defining and naming those themes.

\section{Response rate}

The response rate was 32\%, which was higher than other web-based questionnaires administered in SA (Eiselen \& Nkoutchou 2012). It was also within the range of $25 \%-38 \%$, which has been specified by Marx (2008) as an acceptable questionnaire response rate in South Africa. Thus, the response rate of $32 \%$ was considered sufficient for the purposes of this study.

It should be noted that none of the questions in the questionnaire were compulsory and participants could refrain from answering a particular section or question if they wished so. For that reason, participants did not necessarily answer all the questions.

\section{Ethical consideration}

Ethical clearance was obtained from the Faculty of Economic and Financial Sciences Ethics Committee to distribute the questionnaire to the students. To ensure individual confidentiality, data were recorded based on the principle of anonymity. Participants were also informed that their participation was voluntary and that they had the option to withdraw from the study at any time without prejudicing themselves. To ensure the confidentiality of the data, electronic consent was obtained from the participants and all data were collated and reported on as a unit. The questionnaire was pilot-tested by a selected group of students and two academics to gauge the questionnaire's perceived face validity. The questions were drawn from the literature, which led the researchers to believe that the instrument displayed content validity.

\section{Findings and discussion Respondent profile}

A total of 113 responses were received from the student population. Of this sample, $54(47.8 \%)$ were female respondents, $58(51.3 \%)$ were male respondents and one $(0.9 \%)$ was non-binary. The majority of the respondents, $76(67 \%)$ spoke an indigenous South African or African language. English was spoken by $25(22.1 \%)$ of the respondents, Afrikaans by seven (6\%) and European or other languages by two $(1 \%)$ of the respondents as a home 
language. The majority of the respondents (97.3\%) were between the ages of 18 and 22 years and only 34 (30.1\%) were first-generation students, that is, the first from their families studying at a higher education institution. Statistical analysis indicated that there were negligible variances in the responses between the demographical groupings of the population that would have any meaningful insight into the responses from students.

\section{Students' perceptions of skills needed by a successful chartered accountant}

One of the open-ended questions asked students to describe the skills that they think a successful CA should possess. Their views are captured in the four themes here.

\section{Ethical principles and values}

A key skill that students believed a CA should possess was that of ethical behaviour. Examples of words that were used to describe these qualities were 'ethics', 'integrity', 'professional behaviour' and 'confidentiality'. Accounting professionals are required to act ethically and adhere to a professional code of conduct (International Federation of Accountants [IFAC] 2006). Ethical behaviour is the 'cornerstone of the accounting profession' and, therefore, critically important to instil in accounting students (Barac \& Du Plessis 2014:65). It is, therefore, encouraging to note that students also viewed it as a critical skill that a successful CA should possess, as summed up by this student's comment:

'A CA must be competent and possess integrity while also complying with professional ethical standards.' (P33, female, 19 years old)

\section{Critical thinking skills}

Another skill mentioned by students was critical thinking skills. Students used words such as 'analytical thinking', 'critical thinking', 'problem-solving', 'decision-making skills' and 'creativity'. Students elaborated on this theme with the following comments:

'Critical thinking, ability to adopt to different situations and circumstances, ability to think ahead and not just short term.' (P72, female, 21 years old)

'A CA with good analytical skills has the ability to solve complex problems using a logical informed decision-making.' (P32, male, 25 years old)

This is in line with a study conducted by Jackling and De Lange (2009), which found that accounting graduates perceived problem-solving, thinking creatively and thinking analytically as three of the four most important qualities for career advancement (the other skill being to communicate effectively). Albrecht and Sack (2000) suggested that the accounting curriculum should stop focusing on mere technical knowledge but rather on the development of critical thinking skills that will in the end also increase knowledge.

\section{Technological skills}

Many students mentioned the importance of possessing computer or technological skills. Some linked these important skills to the Fourth Industrial Revolution and the role that artificial intelligence and big data will play, as evidenced by the following comments:

'Computer skills, given the fourth industrial revolution.' (P10, female, 20 years old)

'To apply such artificial intelligence in analysing big data to make better viable decisions for the entity.' (P26, female, 19 years old)

Several students also mentioned good computer skills in the light of the ability to use Microsoft Excel effectively. As Microsoft Excel is a widely applied programme with many functions, learning the programme would not only result in mastering of the software but would also develop critical and analytical thinking skills (Lee et al. 2019; Willis 2016).

\section{Interpersonal skills}

The last category of skills mentioned by the students was the all-important interpersonal skills category. Here students mentioned 'communication skills', 'conflict resolution skills', 'leadership skills', 'people skills', 'listening skills' and being a 'team player'. The comments also showed that students understood the importance of hard work, having a good attitude and applying the 'human touch' (Al-Htaybat, Von Alberti-Alhtaybat \& Alhatabat (2018:340)

'Persistent and positive.' (P35, female, 23 years old)

'Leadership and management, diligence and work ethic.' (P42, female, 20 years old)

'Hard worker and being able to work in a team.' (P64, female, 20 years old)

'Ethical, hard worker and going the extra mile.' (P73, male, 22 years old)

\section{Findings: Board game (Commerce 100)}

Based on the students' views of the pervasive skills that a successful CA should possess, this study further considers which of these skills the students perceive to have been developed through participation in the games. The qualitative and quantitative findings for the board game are combined in this section to show the perceptions of students on the development of skills and what they learned from playing the game in their first year of study. Table 1 shows the skills that students believed were best developed through the board game. These are ranked according to the mean for each of the 12 skills as described in the SAICA Competency Framework and discussed in the introduction to the article.

Based on the given results, students perceived that strategic thinking, critical thinking and professionalism were the top three skills that were most developed through the board 
TABLE 1: Development of pervasive skills through the board game (Commerce 100).

\begin{tabular}{lcccccccccc}
\hline Pervasive skills & $\mathbf{1}$ & $\mathbf{2}$ & $\mathbf{3}$ & $\mathbf{4}$ & $\mathbf{5}$ & $\boldsymbol{N}$ & Mean & MD & SD & Rank \\
\hline Strategic thinking & 4 & 2 & 1 & 42 & 64 & 113 & 4.42 & 5 & 0.894 & 1 \\
Critical thinking & 4 & 3 & 3 & 41 & 62 & 113 & 4.36 & 5 & 0.936 & 2 \\
Professionalism & 4 & 6 & 4 & 38 & 61 & 113 & 4.29 & 5 & 1.015 & 3 \\
Problem-solving & 3 & 5 & 6 & 42 & 57 & 113 & 4.28 & 5 & 0.949 & 4 \\
Communication (verbal) & 4 & 5 & 2 & 49 & 53 & 113 & 4.26 & 5 & 0.962 & 5 \\
Time management & 4 & 8 & 5 & 38 & 58 & 113 & 4.22 & 5 & 1.058 & 6 \\
Communication (listening) & 4 & 6 & 1 & 54 & 48 & 113 & 4.20 & 4 & 0.965 & 7 \\
Ethical awareness & 3 & 7 & 11 & 42 & 50 & 113 & 4.14 & 5 & 1.008 & 8 \\
Influencing others & 4 & 5 & 14 & 43 & 47 & 113 & 4.10 & 5 & 1.017 & 9 \\
Leadership & 2 & 14 & 14 & 32 & 51 & 113 & 4.03 & 5 & 1.114 & 10 \\
Teamwork & 8 & 14 & 9 & 34 & 48 & 113 & 3.88 & 5 & 1.280 & 11 \\
Communication (writing) & 7 & 21 & 17 & 42 & 26 & 113 & 3.52 & 4 & 1.211 & 12 \\
\hline
\end{tabular}

Note: 1 , strongly disagree; 2 , disagree; 3 , neither agree nor disagree; 4 , agree; 5 , strongly agree; $N$, number of students who answered the question; $\mathrm{M}$, mean; MD, median; $\mathrm{SD}$, standard deviation

game. This is a reasonable conclusion as the game requires students to think critically and strategically when responding to risks, opportunities and world events relating to their chosen company. During the game, students are required to listen to facilitators regarding instructions on how to play the game; they are also required to interact and communicate with other students. Thus, the students also perceived the skills of verbal and listening communication to be the fifth and seventh most developed skills in this project.

The open-ended question on this game asked students whether they enjoyed playing it and if so, what was the main lesson learnt from playing the game. The question generated a highly positive response from the majority of students, showing that they indeed enjoyed playing the game. Only five negative responses were recorded. Unfortunately, the students did not elaborate on the reasons for this, except for one response which stated: 'no, it was quite stressful and I didn't gain anything valuable from it'.

The gains that the students derived from playing the game could be summarised in three main themes, namely, skills were developed, learning was collaborative and fun and a connection to real life was established.

\section{Skills developed}

Students indicated that several skills were developed through the board game, confirming the views of Calabor, Mora and Moya (2019) that serious games provide an excellent way to develop problem-solving, decision-making and team work skills. Extracts from the responses that imply skills development include 'critical thinking', 'strategising and solving problems', 'communication skills' and 'how to manage time'. The skills mentioned by the students in the qualitative responses also correspond with the results from Table 1. The following quotes elaborate on the skills developed:

'I learnt that the ability to critically assess a situation and find a way to solve an issue is within me.' (P2, female, 20 years old)

'Strategy is important when facing uncertainty.' (P33, male, 25 years old)
'I mainly learnt how to communicate effectively, and how to listen to, and learn from others. More than anything, I learnt how to think on my feet within a limited time given.' (P110, female, 19 years old)

\section{Learning is collaborative and fun}

One of the benefits of game-based learning is the collaborative environment in which it is situated, promoting fun and effective learning (Carenys \& Moya 2016). The responses contained words such as 'working together', 'fun while learning' and 'team work'. Students confirmed this with the following views:

'More than anything I learnt that team work is dream work. Working together helps us get ahead faster than doing it alone.' (P10, female, 20 years old)

'I learnt that I could have fun while learning.' (P31, female, 22 years old)

\section{Real-life connection}

It is important that educational settings provide students with transferable knowledge and skills, allowing them to make the connection with what they may experience in the real world (Kennedy \& Dull 2008). The students showed their appreciation of the interaction with current CAs (SA) as well as the focus on real-life problems:

'Just the interaction of people who have already obtained the CA (SA) designation ...' (P4, male, 22 years old)

'I learnt how difficult it is to be $\mathrm{CEO}$ but also the power you have as CEO.' (P12, male, 18 years old)

'I learnt the importance of knowing what's happening around the corporate world.' (P96, female, 20 years old)

'I got an idea of how managers solve real-life problems.' (P109, male, 18 years old)

\section{Findings: 60 seconds (Accounting 200)}

The qualitative and quantitative findings (mixed method) for the 60 Seconds game were also combined in this section to show the perceptions of students regarding the development of skills and what they learned from playing the game in their second year of study. Table 2 shows the skills that students believed were developed the best through the 60 Seconds game, ranked according to the mean for each of the 12 skills.

The results indicate that students perceived teamwork to be the most developed pervasive skill in this short, informal game. This was followed closely by communication (listening) in second place and time management in third place. This is a reasonable deduction as the game required students to work in teams, listen to descriptions given by their team members in order to formulate their answer within a time limit of 60 Seconds. Critical thinking and strategic thinking were ranked as fifth and sixth, respectively, showing that students understood that these skills were important in a game of this nature in which time was limited and had to be maximised in order to obtain the 
TABLE 2: Development of pervasive skills through the 60 seconds game (Accounting 200).

\begin{tabular}{lcccccccccc}
\hline Pervasive skills & $\mathbf{1}$ & $\mathbf{2}$ & $\mathbf{3}$ & $\mathbf{4}$ & $\mathbf{5}$ & $\boldsymbol{N}$ & Mean & MD & SD & Rank \\
\hline Teamwork & 4 & 1 & 1 & 32 & 73 & 111 & 4.52 & 5 & 0.87 & 1 \\
Communication (listening) & 4 & 0 & 0 & 37 & 70 & 111 & 4.52 & 5 & 0.83 & 2 \\
Time management & 3 & 4 & 1 & 31 & 71 & 110 & 4.48 & 5 & 0.91 & 3 \\
Communication (verbal) & 5 & 1 & 1 & 38 & 67 & 112 & 4.44 & 5 & 0.93 & 4 \\
Critical thinking & 3 & 3 & 2 & 37 & 65 & 110 & 4.44 & 5 & 0.88 & 5 \\
Strategic thinking & 3 & 3 & 5 & 34 & 65 & 110 & 4.41 & 5 & 0.91 & 6 \\
Influencing others & 4 & 4 & 8 & 32 & 62 & 110 & 4.31 & 5 & 1.01 & 7 \\
Ethical awareness & 5 & 7 & 11 & 39 & 49 & 111 & 4.08 & 5 & 1.10 & 8 \\
Professionalism & 4 & 11 & 6 & 42 & 48 & 111 & 4.07 & 5 & 1.10 & 9 \\
Problem-solving & 6 & 8 & 5 & 47 & 44 & 110 & 4.05 & 4 & 1.11 & 10 \\
Leadership & 5 & 9 & 12 & 38 & 47 & 111 & 4.02 & 5 & 1.13 & 11 \\
Communication (writing) & 10 & 27 & 16 & 28 & 30 & 111 & 3.37 & 5 & 1.35 & 12
\end{tabular}

Note: 1 , strongly disagree; 2 , disagree; 3 , neither agree nor disagree; 4 , agree; 5 , strongly agree; $N$, number of students who answered the question; $\mathrm{M}$, mean; $\mathrm{MD}$, median; $\mathrm{SD}$, standard deviation.

most correct answers in the limited time given. Leadership and written communication were ranked as the least developed skills. This stands to reason as the game does not create an opportunity for leadership and written communication is not needed as the game is based on verbal communication with team members.

As with the board game, the same question was asked to the students regarding the 60 Seconds tutorial game. The game received an overwhelmingly positive response from the students, with only one student indicating that he or she did not enjoy the game or learn anything from it. The main benefits derived from the game can be summarised in three themes, namely, knowledge creation, development of communication skills and an appreciation that accounting can be fun.

\section{Knowledge creation}

Several students commented that each person creates knowledge and understanding differently, but that we can learn from one another. This is in line with a key assumption of constructivism insofar as learners not only develop knowledge for themselves but also through social interaction with peers (Schunk 2012). Quotes that elaborate on this include:

'We all interpret and understand the same content in different ways.' (P2, female, 20 years old)

'I learnt that acc200 is not what you actually study only; it's about understanding it in the world we live in.' (P16, female, 20 years old)

'I learnt from my peers as they described concepts in their perspective which helped me understand other things clearer.' (P45, female, 20 years old)

'I enjoyed having an opportunity to learn from others' interpretations and thought processes surrounding accounting principles.' (P66, female, 20 years old)

\section{Development of communication skills}

The 60 Seconds game required different communication skills, the ability to read and interpret a concept from the card, the skill to explain it to another student and expert listening skills. Several students commented on the importance of communication in its different forms for successfully playing the game:

'I learnt the importance of being precise and clear when giving clues, therefore enhancing my verbal communication and how to listen attentively, improving my listening skill.' (P110, female, 19 years old)

'It is important to clearly communicate with your partner so as to be able to answer the given questions at a given time frame.' (P112, female, 20 years old)

'Ilearned that listening is more important way of communication.' (P68, male, 22 years old)

In their literature review of 53 journal articles on the importance of communication skills for accountants, Siriwardane and Durden (2014) made a distinction between formal and informal communication skills. They found that practitioners viewed informal oral communication skills as more important than the formal skills. They explain that informal oral communication skills can involve giving short presentations, hosting small group discussions and answering client questions. Listening communication skills were also listed as a key skill.

\section{Accounting can be fun}

Several students found the 60 Seconds game to be fun, thereby confirming the view of Gee (2004) that learning should be active and enjoyable. Several students indicated that they learned to be creative in understanding and communicating concepts. Typical word and phrases used by students to support this theme were 'creativity', 'fun' and 'enjoyed it'. Their views are elaborated in the following comments:

'I thoroughly enjoyed the game in the tut, it made learning more fun and informative. I learnt that describing the words actually made it easier to understand them.' (P60, male, 19 years old)

'I learnt the art of having fun in a team effort activity.' (P72, female, 21 years old)

'Who said accountants are boring?' (P42, male, 20 years old)

\section{Comparison of the two games}

The difference between the mean of the highest and lowest ranked pervasive skills in the board game was narrow at 0.9, with a slightly larger difference of 1.15 indicated between the means of the highest and lowest ranked pervasive skills in the 60 Seconds game. This could indicate that students perceived that both the board game and the 60 Seconds game developed pervasive skills, but that the board game developed all the pervasive skills, more so than the 60 Seconds game.

On comparing the perceptions of the participants between the two games, no significant differences were noted (the $p$-values were not smaller than 0.05). Other comparisons between age groups, gender and language groups were also considered, but no statistical difference was observed. 


\section{Limitations and suggestions for further research}

As with all research, this study has also limitations. In this case, the generalisability of the results could be limited given that the questionnaire was only administered to second-year accounting students at one specific institution within only one country. The study further did not provide an objective measure of the pervasive skills development that occurred in students but rather focused on student perceptions. The questionnaire was provided to students without any further clarification and, therefore, the meaning of some of the skills could have been misinterpreted. Subsequent studies could try to minimise these limitations by extending the study to other institutions where the same or similar games are used within the accounting syllabus. It could also be worthwhile to expand this study and investigate the experiences of students through focus groups or interviews.

\section{Conclusion}

Game-based learning is a fun and an innovative way for students to actively and experientially learn and develop pervasive skills. It is best situated within a constructivist learning environment and used as a learning aid rather than the 'be all and end all' of a module or programme. This study compared two games that were played by students in their first and second years of their undergraduate accounting degree and provided insights into the skills that they believed were developed and the learning that occurred. From their comments it could be seen that both games were favourably received and 'ticked all the boxes' in terms of the benefits described by the literature. Both games improved students' knowledge of the specific subject areas, that is, Commerce 100 and Accounting 200, and their reflections showed that they learned from their peers' thought processes and perspectives. The games were played in social settings and, therefore, brought all the benefits of collaborative learning to the students. The overwhelmingly positive responses from most of the students reinforced that games are beneficial in promoting effective learning. It was also noted that both games developed pervasive skills, in line with the students' own perceptions of skills that are important for a successful CA. For the board game, strategic thinking, critical thinking and professionalism were ranked as the top three skills developed, whilst for the 60 Seconds game, it was team work, listening communication and time management.

Both games were non-digital and, therefore, the important technological skills mentioned by the students were not the focus of these two games. The games answered the call of Boghian et al. (2019) to re-introduce board games, with the results showing that the games provided several learning opportunities for the students. This study also showed that it is not always necessary to allocate resources to a learning supplement as the informal and easily created 60 Seconds game was also seen as a very effective learning tool, which developed critical communication and collaboration skills. It could also be argued that in the case of the 60 Seconds game, assessment did not drive the students' behaviour, and learning and skills development occurred despite the game having no bearing on the marks of the students.

\section{Acknowledgements Competing interests}

The authors have declared that no competing interests exist.

\section{Authors' contributions}

All authors contributed equally to this work.

\section{Funding information}

This research received no specific grant from any funding agency in the public, commercial or not-for-profit sectors.

\section{Data availability statement}

The data are available upon reasonable request from the corresponding author.

\section{Disclaimer}

The views and opinions expressed in this article are those of the authors and do not necessarily reflect the official policy or position of any affiliated agency of the authors.

\section{References}

Albrecht, W.S. \& Sack, R.J., 2000, 'Accounting education: Charting the course through a perilous future', Accounting Education 16, 1072.

Al-Htaybat, K., Von Alberti-Alhtaybat, L. \& Alhatabat, Z., 2018, 'Educating digital natives for the future: Accounting educators' evaluation of the accounting curriculum', Accounting Education 27(4), 333-357. https://doi.org/10.1080/0963 9284.2018.1437758

Andre, S.M. \& Smith, B.L., 2014, 'Enhancing the undergraduate accounting curriculum to augment core competencies', Advances in Accounting Education Teaching and Curriculum Innovations 15, 59-78. https://doi.org/10.1108/ S1085-462220140000015002

Barac, K., 2009, 'South African training officers' perceptions of the knowledge and skills requirements of entry-level trainee accountants', Meditari Accountancy Research 17(2), 19-46. https://doi.org/10.1108/10222529200900010

Barac, K. \& Du Plessis, L., 2014, 'Teaching pervasive skills to South African accounting students', Southern African Business Review 18(1), 53-79. https://doi.org/10.25159/ 1998-8125/5645

Boghian, I., Cojocariu, V-M., Popescu, C.V. \& Mata, L., 2019, 'Game-based learning. Using board games in adult education', Journal of Educational Sciences \& Psychology 9(1), 51-57.

Boyle, E.A., Connolly, T.M. \& Hainey, T., 2011, 'The role of psychology in understanding the impact of computer games', Entertainment Computing 2(2), 69-74. https:// doi.org/10.1016/j.entcom.2010.12.002

Boyle, E.A., MacArthur, E.W., Connolly, T.M., Hainey, T. Manea, M., Karki, A. et al., 2014, 'A narrative literature review of games, animations and simulations to teach research methods and statistics', Computers \& Education 74, 1-14. https://doi. org/10.1016/j.compedu.2014.01.004

Braun, V. \& Clarke, V., 2006, 'Using thematic analysis in psychology', Qualitative ResearchinPsychology3(2),77-101.https://doi.org/10.1191/1478088706qp063oa

Brenner, V.C., Jeancola, M.M. \& Watkins, A.L., 2015, 'Using mini-cases to develop AICPA core competencies', Advances in Accounting Education: Teaching and Curriculum Innovations 16, 21-44. https://doi.org/10.1108/S1085-462220150000016002

Bui, B. \& Porter, B., 2010, 'The expectation-performance gap in accounting education: An exploratory study', Accounting Education: An International Journal 19(1-2), 23-50. https://doi.org/10/1080/09639280902875556

Calabor, M.S., Mora, A. \& Moya, S., 2019, 'The future of "serious games" in accounting education: A Delphi study', Journal of Accounting Education 46, 43-52. https:// doi.org/10.1016/j.jaccedu.2018.12.004 
Carenys, J. \& Moya, S., 2016, 'Digital game-based learning in accounting and business education', Accounting Education 25(6), 598-651. https://doi.org/10/1080/09639 education', Accoun

Chow, A.F., Woodford, K.C. \& Maes, J., 2011, 'Deal or no deal: Using games to improve student learning, retention and decision-making', International Journal of Mathematical Education in Science and Technology 42(2), 259-264. https://doi.or g/10.1080/0020739X.2010.519796

Collet, C., Hine, D. \& Du Plessis, K., 2015, 'Employability skills: Perspectives from a knowledge-intensive industry', Education + Training 57(5), 532-559. https://doi. org/10.1108/ET-07-2014-0076

De Freitas, S. \& Routledge, H., 2013, 'Designing leadership and soft skills in educational games: The e-leadership and soft skills educational games design model (ELESS)' British Journal of Educational Technology 44(5), 951-968. https://doi.org/10.1111/ bjet.12034

De Villiers, R., 2010, 'The incorporation of soft skills into accounting curricula: Preparing accounting graduates for their unpredictable futures', Meditari Accountancy Research 18(2), 1-22. https://doi.org/10.1108/10222529201000007

Eiselen, R. \& Nkoutchou, H., 2012, 'Retirement saving behaviour of young adults in the financial services sector', Journal of Economic and Financial Sciences 5(1), 31-48. https://doi.org/10.4102/jef.v5i1.304

Fito-Bertran, A., Hernandez-Lara, A.B. \& Serradell-Lopez, E., 2014, 'Comparing student competences in a face-to-face and online business game', Computers in Human Behavior 30, 452-459. https://doi.org/10.1016/j.chb.2013.06.023

Gee, J.P., 2004, 'Learning by design: Games as learning machines', Interactive Educational Multimedia 8, 15-23.

Given, L.M. (ed.), 2008, The Sage encyclopaedia of qualitative research methods, pp. 697-698, Sage, Thousand Oaks, CA

Grimm, S.D. \& Blazovich, J.L., 2016, 'Developing student competencies: An integrated approach to a financial statement analysis project', Journal of Accounting Education 35, 69-101. https://doi.org/10.1016/j.jaccedu.2016.01.001

Helliar, C., 2013, 'The global challenge for accounting education', Accounting Education 22(6), 510-521. https://doi.org/10/1080/09639284.2013.847319

Henning, E., Van Rensburg, W. \& Smit, B., 2004, Finding your way in qualitative research, Van Schaik Publishers, Pretoria.

Huang, C. \& Hsu, C., 2011, 'Using online games to teach personal finance concepts', American Journal of Business Education 4(12), 33-38. https://doi.org/10.19030/ ajbe.v4i12.6611

International Federation of Accountants (IFAC), 2006, Code of ethics for professiona accountants, viewed 25 September 2019, from https://www.ifac.org/system/ files/publications/files/ifac-code-of-ethics-for.pdf.

Jackling, B. \& De Lange, P., 2009, 'Do accounting graduates' skills meet the expectations of employers? A matter of convergence or divergence', Accounting Education: An InternationalJourna/18(4-5),369-385.https://doi.org/10.1080/09639280902719341

Kavanagh, M.H. \& Drennan, L., 2008, 'What skills and attributes does an accounting graduate need? Evidence from student perceptions and employer expectations', Accounting \& Finance 48(2), 279-300. https://doi.org/10.1111/j.1467-629X 2007.00245.x

Kennedy, F.A. \& Dull, R.B., 2008, 'Transferable team skills for accounting students', Accounting Education: An International Journal 17(2), 213-224. https://doi. org/10.1080/09639280600826166

Kolb, A.Y. \& Kolb, D.A., 2005, 'Learning styles and learning spaces: Enhancing experiential learning in higher education', Academy of Management 4(2), 193-212. https://doi.org/10.5465/amle.2005.17268566

Kolb, D.A., 1984, Experiential learning: Experience as the source of learning and development, Prentice Hall, Englewood Cliffs, NJ.

Lee, L., Shifflett, E. \& Downen, T., 2019, 'Teaching Excel shortcuts: A visualization and game-based approach', Journal of Accounting Education 48, 22-32. https://doi. org/10.1016/j.jaccedu.2019.06.004

Levant, Y., Coulmont, M. \& Sandu, R., 2016, 'Business simulation as an active learning activity for developing soft skills', Accounting Education 25(4), 368-395. https:// doi.org/10.1080/09639284.2016.1191272

Marx, B., 2008, 'An analysis of the development, status and functioning of audit committees at large listed companies in South Africa', Doctoral thesis, University of Johannesburg, Johannesburg.
McEacharn, M., 2005, 'Game play in the learning environment: Who wants to be an accountant? Lawyer? Economist?', Accounting Education 14(1), 95-101. https:// doi.org/10.1080/0963928042000287956

Merino, A. \& Aucock, M., 2017, 'Evaluation of an intervention aimed at developing the personal attributes of prospective entrants into the accounting profession', South African Journal of Accounting Research 31(1), 1-18. https://doi.org/10.1080/102 91954.2015.1105549

Murphy, E.A., 2005, 'Enhancing student learning with Governmental Accounting Jeopardy!', Journal of Public Budgeting, Accounting \& Financial Management 17(2), 223-248. https://doi.org/10.1108/JPBAFM-17-02-2005-B007

Nitkin, M.R., 2011, “'Game of Business”: A game for use in introductory accounting', The Accounting Educators' Journal 21, 131-152.

Qian, M. \& Clark, K.R., 2016, 'Games-based learning and 21st century skills: A review of recent research', Computers in Human Behavior 63, 50-58. https://doi. org/10.1016/j.chb.2016.05.023

Schunk, D.H., 2012, Learning theories, an educational perspective, 6th edn., Pearson Education Inc., Boston, MA.

Seow, P. \& Wong, S., 2016, 'Using a mobile gaming app to enhance accounting education', Journal of Education for Business 91(8), 434-439. https://doi.org/10. 1080/08832323.2016.1256264

Silva, R., Rodriques, R. \& Leal, C., 2019, 'Play it again: How game-based learning improves flow in accounting and marketing education', Accounting Education 28(5), 484-507. https://doi.org/10.1080/09639284.2019.1647859

Siriwardane, H.P. \& Durden, C.H., 2014, 'The communication skills of accountants: What we know and the gaps in our knowledge', Accounting Education 23(2), 119-134. https://doi.org/10.1080/09639284.2013.847329

South African Institute of Chartered Accountants (SAICA), 2019, Competency framework. Detailed guidance for the academic programme, viewed
27 March 2020, from https://www.saica.co.za/Portals/0/LearnersStudents/ 27 March 2020, from https://www.saica.co.za

South African Institute of Chartered Accountants (SAICA), 2020, SAICA competency framework CA2025 - Entry level, viewed 17 November 2020, from https://ca2025.
co.za/wp-content/uploads/2020/03/DRAFT-Competency-framework-Summaryfor-website-30-March-2020.pdf.

Stoner, G. \& Milner, M., 2010, 'Embedding generic employability skills in an accounting degree: Development and impediments', Accounting Education: An International Journal 19(1-2), 123-138. https://doi.org/10/1080/09639280902888229

Strauss-Keevy, M., 2014, 'Education programmes' responsibilities regarding pervasive skills', Journal of Economic and Financial Sciences 7(2), 415-432. https://doi. org/10.4102/jef.v7i2.148

Tanner, M.M. \& Lindquist, T.M., 1998, 'Teaching resource using Monopoly ${ }^{\top \mathrm{M}}$ and teams-games tournaments in accounting education: A cooperative learning teaching resource', Accounting Education 7(2), 139-162. https://doi.org/10.1080/ teaching resource',
096392898331225

Tashakkori, A. \& Creswell, J.W., 2007, 'The new era of mixed methods', Journal of Mixed Methods Research 1(1), 3-7. https://doi.org/10.1177/1558689807309913

Towler, M., Lean, J. \& Moizer, J.D., 2009, 'An exploration of student perception of a business simulation game', International Journal of Management Education 7(2), 69-79.

Tymon, A., 2013, 'The student perspective on employability', Studies in Higher Education 38(6), 841-856. https://doi.org/10.1080/03075079.2011.604408

Viviers, H.A., Fouche, J.P. \& Reitsma, G.M., 2016, 'Developing softs skills (also known as pervasive skills)', Meditari Accountancy Research 24(3), 368-389. https://doi. org/10.1108/MEDAR-07-2015-0045

Webb, J. \& Chaffer, C., 2016, 'The expectation performance gap in accounting education: A review of generic skills development in UK accounting degrees', Accounting Education 25(4), 349-367. https://doi.org/10.1080/09639284.2016.1191274

Willis, V.F., 2016, 'A model for teaching technology: Using Excel in an accounting information systems course', Journal of Accounting Education 36, 87-99. https:// doi.org/10.1016/j.jaccedu.2016.05.002

Xu, Y. \& Yang, Y., 2010, 'Student learning in business simulation: An empirical investigation', Journal of Education for Business 85(4), 223-228. https://doi. org/10.1080/08832320903449469 